\title{
Multi-stage diamond formation in eclogites from Udachnay pipe (Yakutia)
}

\author{
V.S. Shatsky ${ }^{1,2}$, D.A. Zedgenizov ${ }^{1,2}$, A.L. Ragozin ${ }^{1,2}$ \\ ${ }^{I}$ Novosibirsk State University, Russia \\ ${ }^{2}$ Institute of Geology and Mineralogy, Novosibirsk, Russia
}

The studies were conducted with a series of unique of diamondiferous eclogite xenoliths from Udachnaya kimberlite pipe. The high diamond content has made it possible to study the spatial distribution of diamonds and its relationship with matrix mineral. Threedimensional, high-resolution computed X-ray topography (HRCXT) of diamondiferous eclogites has imaged the multitude of diamond and their textural relationships with co-existing minerals.
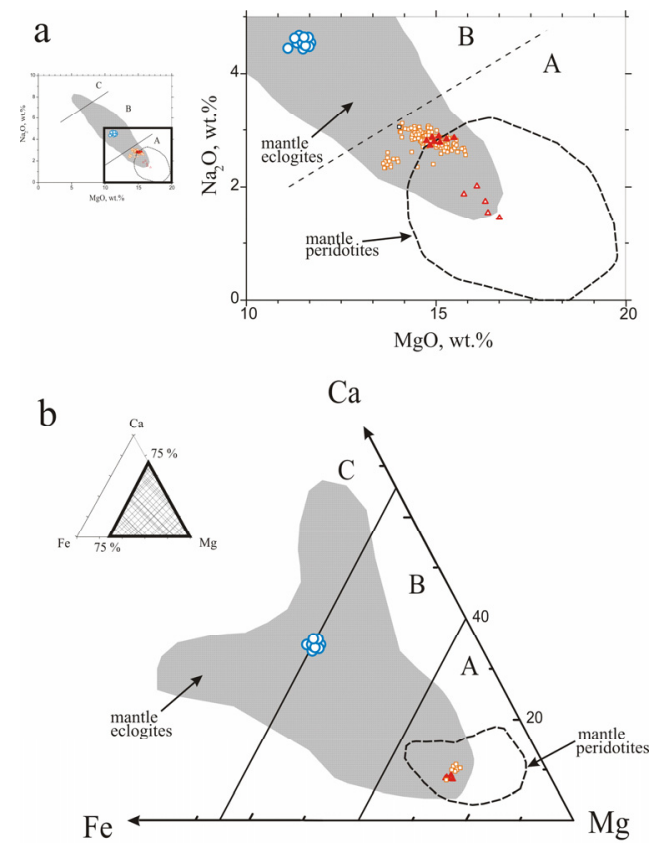

Fig. 1. a - plot of Cpx from the matrix and $\mathrm{Cpx}$ inclusions in diamond, showing the threefold (A, B, C) classification of eclogites according to Taylor and Neal (1989). Orange solid triangles - primary matrix Cpx from xenolith UD-107; orange open triangles - newly formed Cpx from xenolith UD-107; orange open squares - Cpx inclusion in diamond from xenolith UD107; blue open circles - primary matrix Cpx from xenolith UDR. b - plot of garnets from the matrix and garnet inclusions in diamond, showing the threefold (A, B, C) classification of eclogites according to (Coleman et al., 1965). Orange open squares - Grt inclusion in diamond from xenolith UD-107; orange solid triangles - matrix Grt from xenolith UD-107; blue open circles - matrix Grt from xenolith UDR.
The xenolith UD-107 (18 cm in size, $6.9 \mathrm{~kg}$ ) is composed of pale green, often subhedral clinopyroxene (Cpx1), round garnet grains, phlogopite, polyphase sulfide grains and rutile. Clinopyroxene crystals range in size from 5 to $30 \mathrm{~mm}$, and garnets from 1 to $5 \mathrm{~mm}$. Minerals in diamondiferous xenoliths show majorelement compositions transitional between Udachnaya eclogites and those from peridotites (Fig.1). The host clinopyroxene are enriched relative to pyroxenes from Group A eclogites (Taylor and Neal, 1989) and websterites in respect $\mathrm{K}_{2} \mathrm{O}$ and LREE. The xenolith UDR is a rounded xenolith $10 \times 9 \times 5 \mathrm{~cm}$ in size. The size of round garnet grains ranges from 3 to $10 \mathrm{~mm}$. Clinopyroxene anhedral crystals range in size from 5 to $10 \mathrm{~mm}$. According to the classification of Coleman et al. (1965) and Taylor and Neal (1989) the composition of host garnets and clinopiroxenes plot in the Group B field (Fig.1). The xenoliths contain evidence of having experienced a partial melting event. The garnet and pyroxene are crosscut be veins consisting of glass and its replacement products. Clinopyroxene grains are replaced by spongy texture clinopyroxene. The newly formed clinopyroxene has low contents of $\mathrm{K}, \mathrm{Na}$ and $\mathrm{Al}$ and high $\mathrm{Mg \#}$. Temperature of the last equilibration when calculated at the minimal pressure $50 \mathrm{kbar}$ for the eclogite UDR is $1100^{\circ} \mathrm{C}$ similar to that observed for the eclogite xenolith UD-107 $1000^{\circ} \mathrm{C}$ (Shatsky et al., 2008).

Trace element composition of garnet and clinopyroxene from xenoliths were analyzed by LAICP-MS. As seen from the chondrite-normalized REE pattern (Fig.2), the clinopyroxene from eclogite UD107 are enriched in all REE relative to most other eclogite xenoliths from the Udachnaya and South African kimberlite pipes (Sobolev et al., 1994; Jacob et al., 2003). They have the highest HREE content of any clinopyroxenes from the Udachnaya pipe eclogites and are strongly enriched in MREE. The spidergram of the clinopyroxene shows negative anomalies in $\mathrm{Ti}, \mathrm{Zr}$ and $\mathrm{Nb}$ and a positive $\mathrm{Sr}$ anomaly (Fig.3). The REE pattern of the host garnet is similar to those of other garnets from the Udachnaya pipe xenoliths, showing a gentle decrease from $\mathrm{Yb}$ to $\mathrm{Gd}$ and a drastic decrease from $\mathrm{Sm}$ to La (Fig.2). The spidergram shows negative $\mathrm{Sr}$ and $\mathrm{Ti}$ anomalies (Fig.3). We believe that such 
peculiarities of eclogite UD-107 as major-element compositions transitional between Udachnaya eclogites and those from peridotites in combination with high LREE and $\mathrm{K}_{2} \mathrm{O}$ contents in host clinopyroxene reflect the interaction between mantle peridotites and melts rich in $\mathrm{K}$ and LREE.

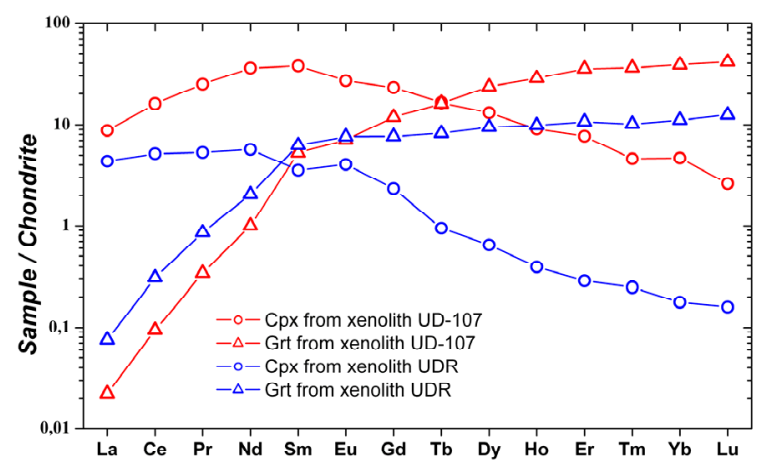

Fig. 2. Rare earth-element patterns for clinopyroxenes and garnets from the matrix of the eclogite xenoliths. Normalized to chondrite values of McDonough and Sun (1995).

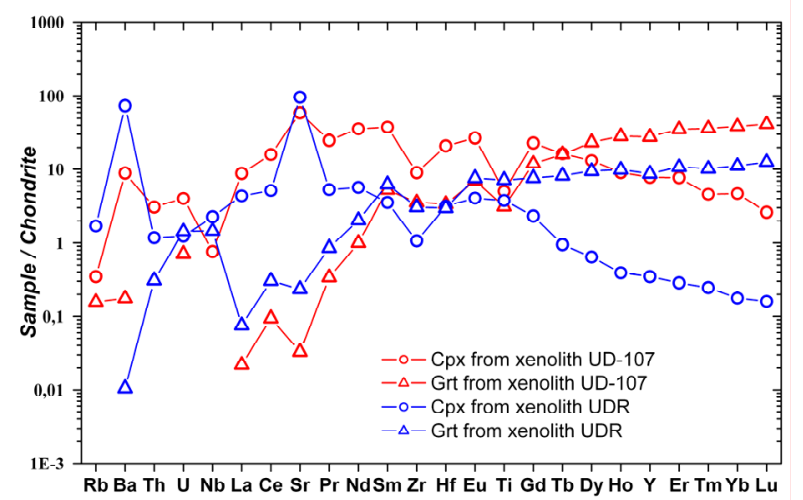

Fig. 3. Trace-element pattern for clinopyroxenes and garnets from the matrix of the eclogite xenoliths. Normalized to chondrite values of McDonough and Sun (1995).

Abundance of highly incompatible trace elements in garnet from eclogite UDR is low. Garnet have steep positive slope in $\mathrm{LREE}_{\mathrm{N}}$ and flat $\mathrm{MREE}_{\mathrm{N}}$ and $\mathrm{HREE}_{\mathrm{N}}$ at to ten times chondritic abundance (Fig.2). The spidergram shows negative $\mathrm{Zr}$ and $\mathrm{Hf}$ anomalies. Garnet has chondritic $\mathrm{Zr} / \mathrm{Hf}$ (Fig.3). Clinopyroxene from sample UDR have convex-upward REE pattern and is LREE-enriched and HREE depleted. Clinopyroxene is characterized by a positive Eu anomaly $(\mathrm{Eu} / * \mathrm{Eu}=1.2-1.52)$. The spidergram of the clinopyroxene shows negative anomalies in $\mathrm{Zr}$ and $\mathrm{Hf}$ and a strong positive $\mathrm{Sr}$ anomaly. The calculated whole rock incompatible trace element composition for the reconstructed whole-rock UDR eclogite exhibit flat, parallel patterns in an MORB-normalized diagram. Eclogite is characterized by low abundances of highly incompatible trace elements except the $\mathrm{Ba}$ and $\mathrm{Sr}$ and exhibit positive $\mathrm{Sr}$ and $\mathrm{Eu}$ anomalies and negative $\mathrm{Zr}$ and $\mathrm{Hf}$ anomalies. The positive $\mathrm{Sr}$ and $\mathrm{Eu}$ anomalies and low REE abundances are consistent with the interpretation that the protholith for the eclogite originate from mafic cumulates.

The distribution of diamond in the xenoliths is extremely irregular. Diamonds are found in the eclogite xenolith mainly in the intergranular spaces and as inclusions in garnet and clinopyroxene. The diamonds in eclogite UD-107 are colorless to canary-yellow and some are black. They are often concentrated in veins and schlieren and range in size from 1 to $5 \mathrm{~mm}$. The diamonds appear to be preferentially located in zones of secondary mineralization. The diamonds show large variations in nitrogen concentration (from 30 to 1900 ppm) and nitrogen aggregation levels. The colorless and yellow diamonds differ from each other in both the total content of nitrogen and aggregation states. The colorless diamonds are characterized by a high degree of aggregation (up to $35 \% \mathrm{~B}$ ) and a high content of nitrogen (up to $1900 \mathrm{ppm}$ ). The yellow diamonds have lower nitrogen contents $(<200 \mathrm{ppm})$. Thus, together with diamonds with high contents of nitrogen and high aggregation state, there are diamonds poor in nitrogen, which almost totally occurs as A-centers. High degrees of nitrogen aggregation in colorless diamonds of the first generation from our xenolith suggest that they formed $\geq 1$ Ga before kimberlite eruption, whereas the yellow diamonds of the second generation (type IaA) were formed shortly before kimberlite emplacement. This suggests that the xenolith contains diamonds of at least two generations. 105 diamonds from the xenolith were polished to expose their mineral inclusions. In all, 162 inclusions were exposed, among which 109 clinopyroxene, 22 garnet, 14 mica, 12 sulfide, 3 rutile, 3 coesite were identified. The greatest difference in chemical composition is observed between micas of the matrix and inclusions in the diamonds. The diamond micas are rich in $\mathrm{SiO}_{2}$ (up to $3.6 \mathrm{f}$.u. against $\leq 3 \mathrm{f}$.u. in the matrix micas) and $\mathrm{TiO}_{2}$. The silica rich composition of the mica in diamond deviates significantly from that of phlogopite in diamond inclusions, kimberlite and lamproite.

The diamonds from xenolith UDR are dominated polycrystalline intergrowth of cuboids, octahedron or dodecahedroid (up to $1.5 \mathrm{~mm}$ long). Morphology and grains size can vary within a cluster and coarser- and fine grade portions can be present. The $\{110\}$ faces exhibit striated surfaces. Dodecahedral faces consisting for repeated small steps of $\{111\}$ during the course of growth. Coated diamonds are also occurring. The grain size varies between 6 to $300 \mu \mathrm{m}$. The cubic diamond crystals and their intergrowths often have a black color owing graphite coat or to the presence of a thin outer rim $(10-20 \mu \mathrm{m})$ with numerous dark microinclusions less then $1 \mu \mathrm{m}$ in size. Raman spectroscopy shows the presence of graphite in some microinclusions. Infrared spectra of cubic diamonds also show lines related to the microinclusions of water $\left(3420\right.$ and $\left.1630 \mathrm{~cm}^{-1}\right)$, carbonates $\left(1430\right.$ and $\left.880 \mathrm{~cm}^{-1}\right)$ and silicates (1050, 1015 and $\left.970 \mathrm{~cm}^{-1}\right)$. The nitrogen content of cubic diamonds varies from 270 to $950 \mathrm{ppm}$ and are of type IaA. The large range in N-content from 32 to $430 \mathrm{ppm}$ 
is also observed among octahedral diamonds. Mixed type Ib-IaA spectra are indicated by IR absorbtion bahds at $1132 \mathrm{~cm}^{-1}$ and $1282 \mathrm{~cm}^{-1}$. The carbon isotopic composition of cubic diamond and polycrystalline aggregates range from -3.5 to $-6.2 \%$ of $\delta^{13} \mathrm{C}$ and for octahedron crystals range from -14.2 to $-15.6 \%$ of $\delta^{13} \mathrm{C}$.

Considerable variation in external and internal morphology, $\mathrm{C}$ isotopic composition, nitrogen content and aggregation state and other infrared spectroscopic properties, occur between diamonds from single xenolith's and also within single crystals. Taken together this observation suggests a history of diamonds involving at least two period of growth. Our investigation testifies about very complicated history of diamond formation in eclogites. Through the combination of HRCXT and hand sample observation it is evident that majority of diamonds are present in intergranular space. Method of diamonds recovering was not permitted to determine exactly locating of studied diamond. In this connection we can not advocated that diamonds are present in the intergranular space and diamonds included in $\mathrm{Cpx}$ and Grt belongs to different growth stage.

\section{References:}

Taylor, L.A., Neal, C.R., 1989. Eclogites with oceanic crustal and mantle signature from Bellsbank kimberlite, South Africa, Part I: mineralogy, petrography, and whole rock chemistry. Journal of Geology 97, 551-567.

Coleman, R.G., Lee, D.E., Brannock, W.W., 1965. Eclogites and eclogites, their difference and similarities. Bulletin Geological Society America 76, 483-508.

Shatsky, V, Ragozin, A., Zedgenizov, D., Mityukhin, S., 2008. Evidence for multistage evolution in a xenolith of diamond-bearing eclogite from the Udachnaya kimberlite pipe. Lithos (in press)

Sobolev, V.N., Taylor, L.A., Snyder, G.A., Sobolev, N.V., 1994. Diamondifferous eclogites from the Udachnaya kimberlite pipe, Yakutia. International Geological Review 36, 42-46.

Jacob, D.E., Schmickler, B., Schulze, D.J., 2003. Trace element geochemistry of coesite-bearing eclogites from the Roberts Victor kimberlite, Kaapval craton. Lithos 71, 337-351.

McDonough, W.F., Sun, S.-S., 1995. The composition of the Earth. Chemical Geology 120, 223-253. 